\title{
REDESAIN EMBUNG ANGSOKAH KABUPATEN SAMPANG
}

\author{
Chandra Eko Prasetyo, Umboro Lasminto, Mohamad Bagus Ansori \\ Jurusan Teknik Sipil - Fakultas Teknik Sipil dan Perencanaan, Institut Teknologi Sepuluh Nopember (ITS) \\ Jl. Arief Rahman Hakim, Surabaya 60111 \\ E-mail : chandraekoprasetyo@gmail.com, umboro@ce.its.ac.id, bagusansor@gmail.com.
}

\begin{abstract}
Abstrak- Pada musim kemarau sebagian besar wilayah di Kabupaten Sampang sering mengalami kekeringan. sungaisungai yang pada musim penghujan banyak terdapat air, pada musim kemarau menjadi berkurang airnya dan di sebagian kawasan terkadang menjadi kering. Sungai Omben adalah salah satu sungai yang pada musim kemarau akan mengalami kekeringan. Kondisi ini membuat masyarakat di sepanjang sungai Omben khususnya masyarakat desa Angsokah kecamatan Omben mengalami kesulitan untuk mendapatkan air bersih. Dari identifikasi data curah hujan 10 tahun dan topografi, pembangunan embung merupakan salah satu alternatif yang dapat diterapkan dalam mengatasi kekurangan air di Desa Angsokah.
\end{abstract}

Perhitungan - perhitungan yang dilakukan dalam perencanaan Embung Angsokah ini meliputi analisa kebutuhan air menggunakan metode linier geometri, analisa kapasitas tampungan menggunakan lengkung kapasitas dan kurva massa, perhitungan curah hujan rencana menggunakan metode pearson type III, debit rencana menggunakan metode hidrograf Nakayasu sedangkan debit andalan dihitung dengan metode FJ Mock, penelusuran banjir menggunakan metode tahap demi tahap (step by step), analisa kestabilan spillway terhadap guling, geser, tegangan tanah dan ketebalan lantai, analisa kestabilan tubuh bendungan terhadap longsor metode Fellenius dan dengan program $D X-S T A B L$ pada saat kondisi embung masih kosong, pada saat muka air maksimum (banjir), pada saat elevasi muka air 3/4 tinggi muka air maksimum, pada saat elevasi muka air $1 / 2$ tinggi air maksimum, dan pada saat elevasi muka air sama dengan elevasi dead storage.

Dari perhitungan yang telah dilakukan diperoleh proyeksi jumlah penduduk pada tahun 2039 sebanyak 2.877 jiwa dengan kebutuhan air per orang $100 \mathrm{lt} / \mathrm{org} / \mathrm{hr}$, kebutuhan air rencana $3,663 \mathrm{~m}^{3} / \mathrm{dtk}$, kapasitas tampungan sebesar $64.752,919 \mathrm{~m}^{3}$, curah hujan rencana periode ulang 25 tahun sebesar 129,354 $\mathrm{mm}$, debit rencana periode ulang tahun sebesar 13,029 $\mathrm{m}^{3} /$ detik, mercu spillway menggunakan mercu Ogee Tipe I dengan elevasi mercu pada $+\mathbf{1 0 3 , 0 0}$ dan elevasi muka air banjir pada $+104,02$. Tubuh bendungan menggunakan urugan tanah dengan kemiringan hulu dan hilir tubuh bendungan adalah 1 : 2 , elevasi puncak berada pada $+\mathbf{1 0 6 , 5 0}$ dan elevasi dasar berada pada $+95,00$. Tinggi jagaan tubuh bendungan dipakai sebesar 2 $\mathrm{m}$. Tubuh bendungan diperkuat dengan geotexlie dipasang melintang 11 lapis type geotextile yang dipilih adalah type Stabilenka 800/100, sedangkan arah memanjang dipasang Geomembran HDPE tebal $2 \mathrm{~mm}$. Saluran pengambilan menggunakan pipa HDPE diameter $0,20 \mathrm{~m}$ yang selanjutnya ditampung di bak penampungan air.

Kata kunci - kebutuhan air, embung, spillway, geotextile

\section{PENDAHULUAN}

Desa Angsokah merupakan salah satu desa di Kecamatan Omben, Kabupaten Sampang Pulau Madura. Kabupatan Sampang secara umum mempunyai curah hujan yang relatif rendah atau sekitar setengah dari curah hujan di Jawa atau sekitar $1.200 \mathrm{~mm} /$ tahun. Kabupaten Sampang terdiri dari 14 kecamatan yang terdiri dari 186 desa. Desa-desa tersebut sebagian besar merupakan desa rawan air atau sulit air salah satu desa yang mengalami ialah Desa Angsokah. Kondisi struktur geologi / lapisan tanah relatif homogen yang kedap air sehingga permasalahan pokok yang dihadapi daerah ini adalah kesulitan air pada musim kemarau dan terjadi banjir pada musim penghujan. Air tanah yang sangat terbatas dan hanya dititiktitik tertentu saja yang bisa dikembangkan, hal ini membuat wilayah di Kabupaten Sampang sebagian besar terkenal kering dan tertinggal dibandingkan dengan daerah lainnya dibagian utara. Dasar inilah yang mendorong untuk terus mencari lokasi yang bisa digunakan untuk menampung air hujan. Untuk mengatasi permasalahan tersebut perlu dikembangkan potensi sumber daya air dengan membangun waduk kecil atau embung di Desa Angsokah. Desa Angsokah terletak disebelah Timur Laut Kota Sampang dengan jarak 13,00 km. Batas - batas Desa Angsokah Kecamatan Omben adalah sebagai berikut :

$$
\begin{aligned}
& \text { 1. Sebelah Utara : Desa Rapa Laok dan Desa } \\
& \text { Rongoalem. }
\end{aligned}
$$

2. Sebelah Timur : Desa Omben.

3. Sebelah Selatan: Desa Sogian dan Desa Napo.

4. Sebelah Barat : Desa Jragoan.

Embung ini berfungsi untuk menyimpan air hujan pada saat musim penghujan dan dapat dimanfaatkan pada saat musim kemarau. Rencana bangunan embung Angsokah yang diusulkan merupakan bekas dari embung lama yang 
dibanguan oleh Dinas Perhutani. Dalam perencanaan Embung terdapat beberapa aspek yang perlu diperhatikan antara lain, kapasitas embung, kekuatan dan kestabilan konstruksi, efisiensi dan ketepatgunaan prosedur perhitungan yang sesuai dengan standar teknis yang berlaku.

\section{METODE PENELITIAN}

Konsep penyelesaian pada perencanaan yang dipakai dalam penulisan tugas akhir ini adalah untuk melakukan perencanaan apakah Embung Angsokah ini mampu menampung kebutuhan air penduduk pada musim penghujan dan dapat dimanfaatkan pada saat musim kemarau. Urutan konsep penyelesaian yang dipakai adalah sebagai berikut :

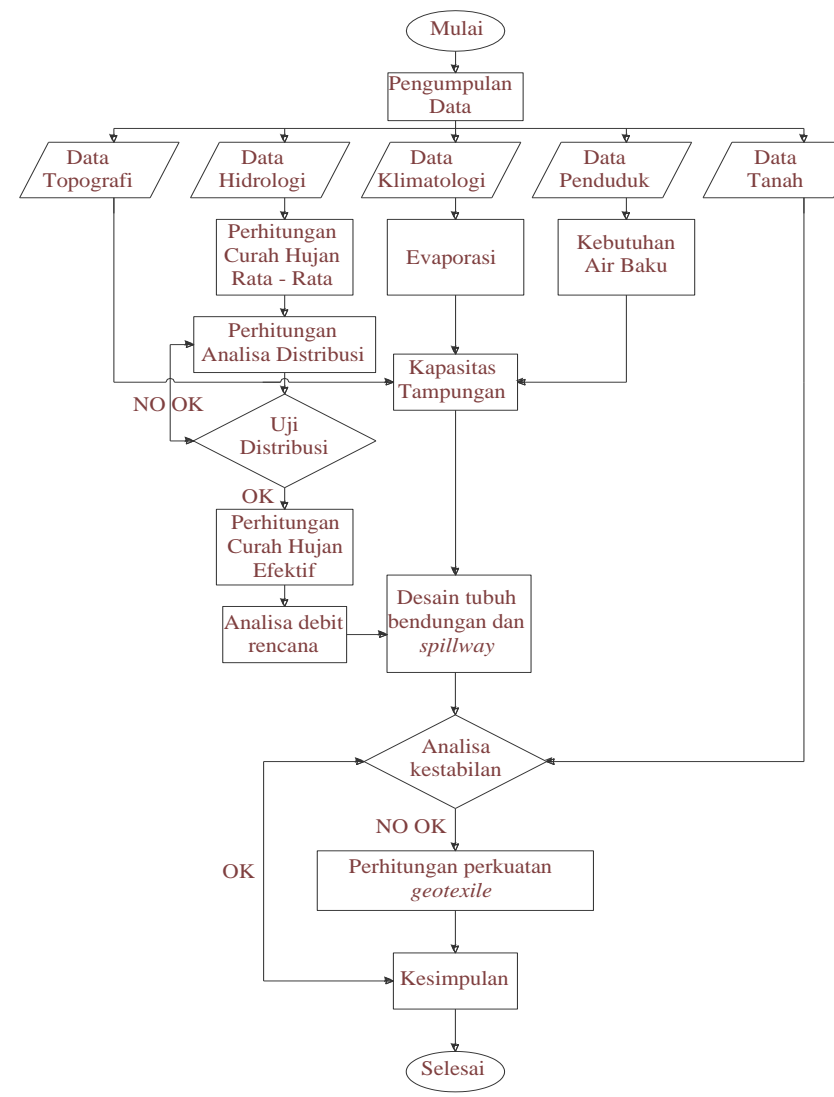

Gambar 1.Langkah pengerjaan tugas akhir.

\section{HASIL DAN DISKUSI}

\section{A. Proyeksi Kebutuhan Air Penduduk}

Metode yang digunakan dalam memproyeksi pertumbuhan penduduk adalah Metode Linear Geometri [1], dari hasil analisa penduduk didapatkan jumlah penduduk pada tahun 2039 adalah 2.877 jiwa.
Dalam menentukan kebutuhan air digunakan besaran -besaran yang mengacu pada dasar - dasar perencanaan dan evaluasi kebutuhan air bersih yang telah ada. Dari hasil analisa data, didapatkan kebutuhan air penduduk sebesar 11,773 liter / detik.

\section{B. Analisa kapasitas Tampungan}

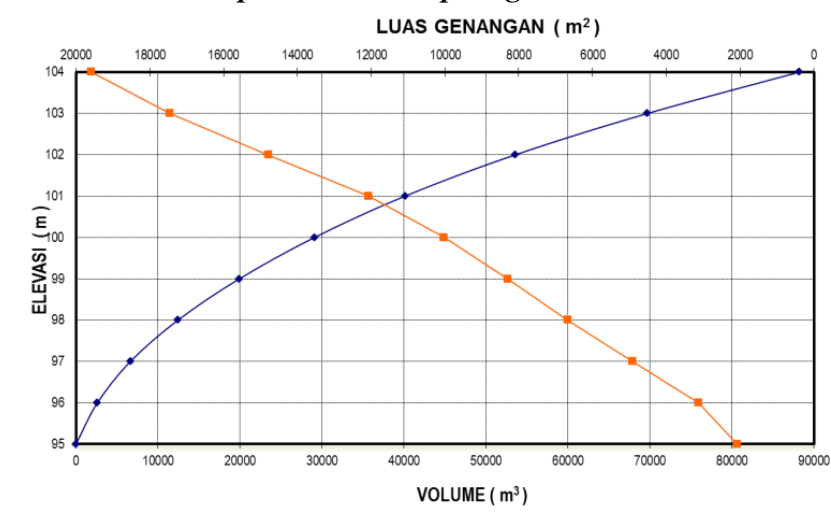

Gambar 2.Grafik Hubungan Elevasi, Luas Genangan dan Volume

Analisa kapasitas tampungan didapatkan dari data topografi. Dari analisa ini didapatkan grafik hubungan antara elevasi dengan luas volume suatu waduk. Dari hasil perhitungan didapatkan grafik seperti pada gambar 2 .

Dari hasil analisa perubahan volume waduk akibat debit inflow dan outflow. Debit inflow didapat dari perhitungan analisa debit tersedia dengan metode FJ Mock, sedangkan debit outflow diperoleh dari perhitungan evaporasi dan perhitungan kebutuhan air penduduk. Maka dari hasil analisa tersebut yaitu :

1. Kapasitas mati $=395,00 \mathrm{~m}^{3}$

2. Kapasitas efektif $=64.357,919 \mathrm{~m}^{3}$

3. Kapasitas Total = Kap. Mati + Kap. Efektif $=395,00 \mathrm{~m}^{3}+64.357,919 \mathrm{~m}^{3}$

$=64.752,919 \mathrm{~m}^{3}$

Jika diplotkan pada grafik lengkung kapasitas, maka didapatkan elevasi $+102,9 \approx+103$ yang digunakan sebagai elevasi rencana mercu bendungan. Selanjutnya dapat di buat kurva massa yang terhadap debit inflow dan kebutuhan air. 


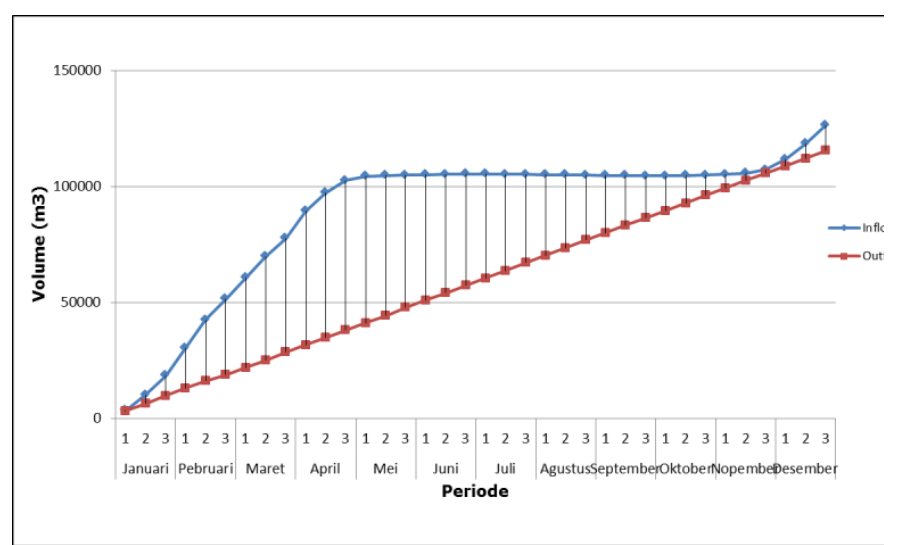

Gambar 3. Kurva Massa Debit Inflow dan Kebutuhan Air

\section{Analisa Data Curah Hujan}

Data curah hujan yang diperlukan untuk penyusunan suatu rancangan pemanfaatan air adalah curah hujan rata-rata di daerah aliran sungai, yaitu Sta. Kadungdung, Sta. Omben dan Sta. Robatal. Untuk penentuan luas pengaruh stasiun hujan dengan Metode Thiesen.

\section{Analisa Distribusi Frekuensi}

Analisa distribusi frekuensi ini dimaksudkan untuk mendapatkan besaran curah hujan rencana yang ditetapkan. Untuk keperluan analisa ditetapkan curah hujan dengan periode ulang tertentu dengan menggunakan metode Pearson Type III, diperoleh harga curah hujan periode ulang 25 tahun yaitu $129,354 \mathrm{~mm}$.

\section{E. Perhitungan Debit Banjir Rencana}

Untuk membuat hidrograf banjir pada sungai sungai yang tidak ada atau sedikit sekali data hidrograf banjirnya, maka perlu dicari karakteristik atau parameter daerah pengaliran tersebut terlebih dahulu, misalnya waktu untuk mencapai puncak hidrograf, lebar dasar saluran luas, kemiringan saluran, koefisien limpasan dan sebagainya. Dalam perhitungan hidrograf satuan spillway pada Embung Angsokah ini digunakan metode hidrograf sintetik Nakayasu yaitu grafik hubungan antara debit yang mengalir dan waktu.

Dengan menggunakan grafik hidrograf Nakayasu kemudian dapat dihitung debit maksimum terbesar pada periode ulang 25 tahun adalah sebesar $13,029 \mathrm{~m}^{3} /$ detik.

\section{F. Penelusuran Banjir}

Tujuan penelusuran banjir adalah untuk mengetahui daya tampung embung terhadap banjir rencana yang terjadi. Dasar perhitungannya adalah

$$
I-O=\frac{d s}{d t}
$$

I $=$ Debit air yang masuk ke dalam waduk $\left(\mathrm{m}^{3} /\right.$ detik $)$

$\mathrm{O}=$ Debit air yang keluar ke dalam waduk $\left(\mathrm{m}^{3} /\right.$ detik)

$\mathrm{dS}=$ besarnya tampungan waduk (m3)

$\mathrm{dt}=$ periode penelusuran (detik, jam atau hari)

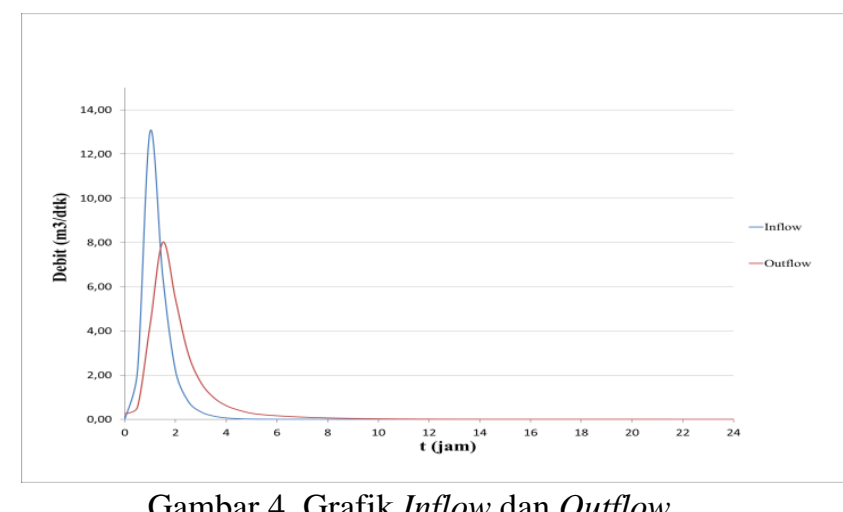

Hasil analisa penelusuran banjir didapatkan hidrograf banjir seperti gambar 4. Dari perhitungan penelusuran banjir didapatkan debit outflow sebesar $8,014 \mathrm{~m}^{3} /$ detik.

\section{G. Perencanaan Spillway}

Bangunan pelimpah merupakan suatu bangunan yang harus mampu melimpahkan kelebihan air dari debit banjir yang akan dibuang sehingga kapasitas bendungan dapat dipertahankan sampai batas maksimum. Direncanakan memakai tipe mercu Ogee type I. Tinggi spillway adalah $4 \mathrm{~m}$ dengan lebar $10 \mathrm{~m}$. Direncanakan lengkap dengan bagianbagiannya, yaitu : saluran pengatur, saluran transisi, saluran peluncur lurus, saluran peluncur terompet dan kolam olak USBR type III serta saluran tambahan [3]. Analisa hidrolika bangunan spillway secara lengkap dapat dilihat pada gambar desain spillway dapat dilihat pada Gambar 5. 


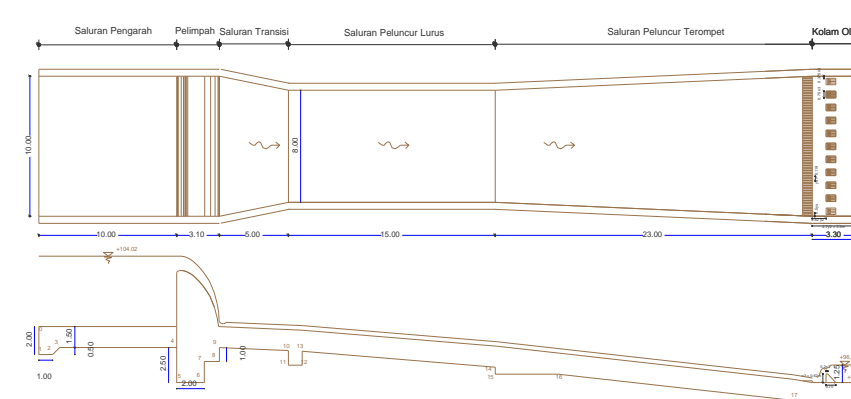

Gambar 5.Desain Spillway

Dalam perencanaan spillway juga dihitung stabilitas bangunannya. Hasilnya dapat dilihat pada Tabel 1. Dan dari hasil analisa stabilitas spillway dapat disimpulkan bahwa spillway yang direncanakan masih aman.

Tabel 1

Hasil Anlisa Stabilitas Spillway

\begin{tabular}{|c|c|c|c|c|c|c|}
\hline \multirow{2}{*}{\multicolumn{2}{|c|}{ Kontrol }} & \multicolumn{2}{|c|}{ Air Normal } & \multicolumn{2}{|c|}{ Air Banjir } & \multirow{2}{*}{ Ket. } \\
\hline & & Hasil & Batas & Hasil & Batas & \\
\hline Guling & & 2,056 & $\geq 1,5$ & 1,502 & $\geq 1,5$ & ok \\
\hline Sliding & & 1,588 & $\geq 1,2$ & 1,282 & $\geq 1,2$ & ok \\
\hline \multirow[t]{2}{*}{ Daya Dukung : } & $\operatorname{Max}$ & 1,784 & $\leq 41,69$ & 2,400 & $\leq 41,69$ & ok \\
\hline & Min & 0,773 & $\geq 0$ & 0,15 & $\geq 0$ & ok \\
\hline Ketebalan lantai & & 1,54 & $\leq 2$ & 1,89 & $\leq 2$ & ok \\
\hline
\end{tabular}

\section{H. Perencanaan Bendungan}

Tubuh bendungan direncanakan dengan tipe homogen berupa urugan tanah (earth fill), dimana material tanah diambil dari daerah genangan atau sekitar lokasi embung. Dalam perencanaannya perlu diperhatikan beberapa langkah perhitungan, yaitu :

1) Menentukan tinggi jagaan

2) Menentukan tinggi puncak bendungan

3) Menentukan lebar mercu bendungan

4) Menentukan kemiringan lereng urugan

5) Menentukan garis depresi

6) Analisa Stabilitas

Dari hasil perhitungan didapat : tinggi jagaan $=2$ $\mathrm{m}$, tinggi puncak bendungan $11,5 \mathrm{~m}$, lebar mercu bendungan $6 \mathrm{~m}$, kemiringan lereng urugan didapat perbandingan horizontal : vertikal $=2: 1$. Untuk analisa garis depresi dan bidang longsor metode Fellenius dapat dilihat pada gambar 6.

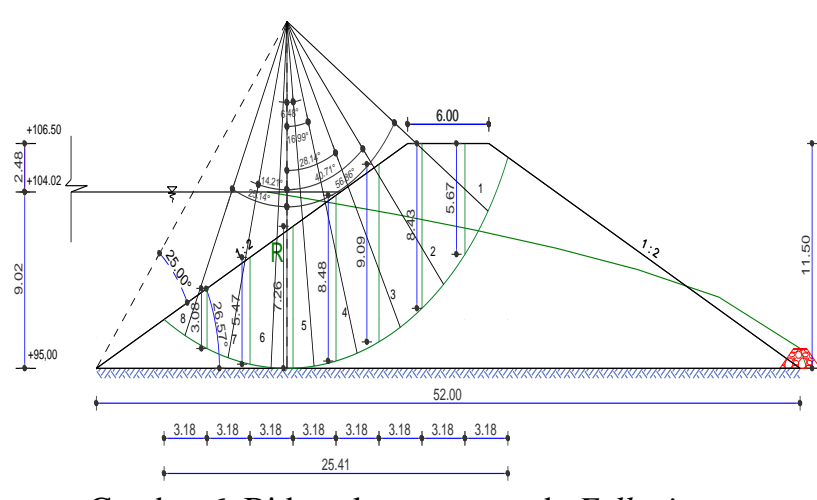

Gambar 6. Bidang longsor metode Fellenius

Analisa stabilitas tubuh bendungan Embung Angsokah menggunakan metode Fellenius dan dengan software XSTABL. Perhitungan dilakukan kondisi normal dan gempa saat embung masih kosong, muka air maksimum (banjir), elevasi MA $3 / 4$ tinggi air maksimum, elevasi MA $1 / 2$ tinggi air maksimum, dan elevasi MA sama dengan elevasi dead storage. Untuk hasilnya dapat dilihat pada rekapitulasi tabel 1 :

Tabel 2

Hasil Anlisa Stabilitas Tubuh Bendungan

\begin{tabular}{|c|l|c|c|c|c|c|c|}
\hline \multirow{2}{*}{ No. Kondisi } & \multicolumn{2}{|c|}{ Hulu } & \multirow{2}{*}{ Keputusan } & \multicolumn{2}{|c|}{ Hilir } & \multirow{2}{*}{ Keputusan } \\
\cline { 3 - 4 } & & FS Hitung & FS jijn & & FS Hitung & FS jijn & \\
\hline 1 & Kondisi Embung masih kosong & 1,171 & 1,20 & tidak ok & 1,171 & 1,20 & tidak ok \\
\hline 2 & Muka air maksimum ( banjir $)$ & 1,227 & 1,20 & 0k & 1,179 & 1,20 & tidak ok \\
\hline 3 & Elevasi MA 3/4 tinggi air maksimum & 1,296 & 1,20 & 0k & 1,179 & 1,20 & tidak ok \\
\hline 4 & Elevasi MA 1/2 tinggi air maksimum & 1,232 & 1,20 & ok & 1,178 & 1,20 & tidak ok \\
\hline 5 & Elevasi dead storage & 1,176 & 1,20 & tidak ok & 1,178 & 1,20 & tidak ok \\
\hline
\end{tabular}

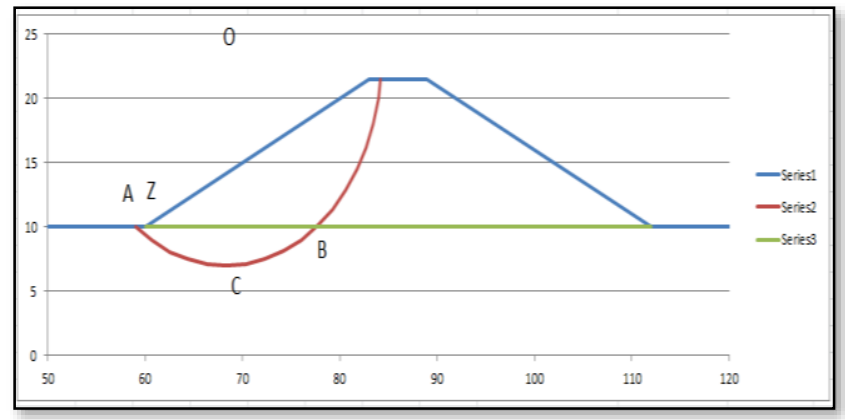

Gambar 7. Bidang longsor output XSTABL.

Dari hasil perhitungan stabilitas di dapat kondisi bendungan yang kritis. Nilai $\mathrm{FS}_{\text {kritis }}=1,171$ (hitungan manual metode Fellenius), sedangkan dengan software XSTABL FS $\mathrm{Fritis}=1,194$. Bila FSTERJADI < FSIJIN maka konstruksi bendungan mengalami kegagalan struktur maka dibutuhkan perkuatan, dalam penyelesaian masalah Tugas Akhir ini perkuatan tubuh bendungan menggunakan geotextile. 


\section{Perencanaan Geotextile}

Pada perencanaan Geotextile untuk Embankment, perlu ditinjau stabilitas pada :

- Internal stability

- Foundation stability

- Overall stability

Dari hitungan tubuh bendungan dipasang geotextile 11 lapis dari ketinggian 11,5 m. Panjang geotextile yang ditanam (L) pada satu layer timbunan :

$$
\mathrm{L}=\mathrm{Le}+\mathrm{Ld}
$$

\section{Dimana :}

- $\mathrm{Ld}=$ (koordianat $\mathrm{X}$ bidang longsor lapisan $\mathrm{i}$ geotextile terpasang) - (koordinat tepi timbunan lapisan i geotextile dipasang).

- Le = Panjang geotextile yang berada dibelakang bidang longsor (minimum $1 \mathrm{~m}$ )

Berikut perbandingan antara gambar rencana tubuh bendungan menggunakan geotextile dengan desain gambar tubuh bendungan yang ada dilapangan :

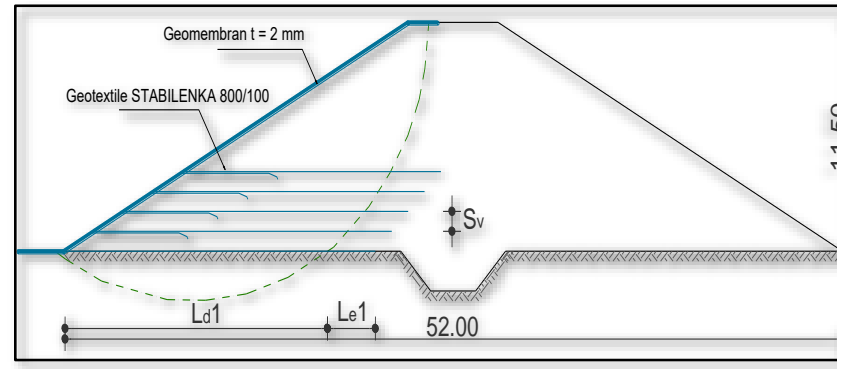

Gambar 8. Tubuh bendungan dengan perkuatan geotexile.
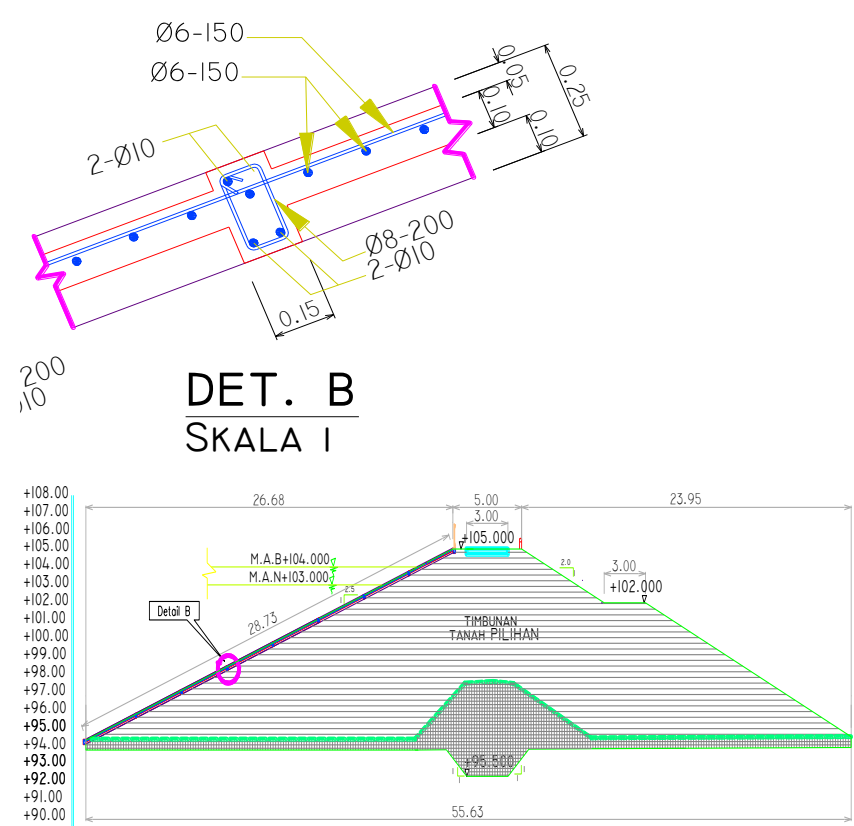

Gambar 9. SID Embung oleh PT. Angga Anugrah Konsultan

\section{J. Denah Embung Angsokah}

Setelah diketahui perencanaan bangunan spillway dan bendungan. Gambar perencanaan denah secara lengkap dapat dilihat pada gambar 9 .

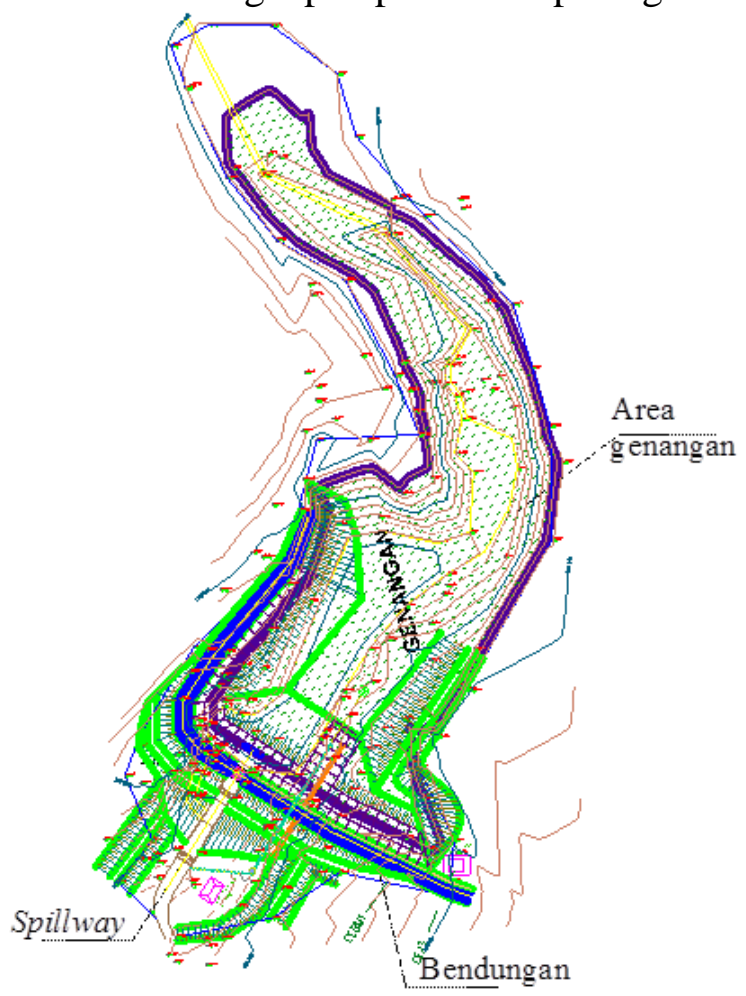

Gambar 9. Denah Embung Angsokah

\section{KESIMPULAN}

1. Dari uraian dan perhitungan pada bab-bab sebelumnya dapat disimpulkan bahwa :

2. Jumlah kebutuhan air total pada tahun 2039 sebesar 3,663 liter / detik.

3. Ketersediaan air pada Embung Angsokah dari analisa kebutuhan air penduduk dan curah hujan andalan yang ada sebesar $64.357,919 \mathrm{~m} 3$. Kapasitas mati sebesar 395,00 m3 dan kapasitas total tampungan sebesar 64.752,919 m3. Dari kapasitas tampungan total tersebut mampu memenuhi kebutuhan air penduduk di Desa Angsokah.

4. Dimensi spillway:

Tipe mercu = Ogee tipe 1

Lebar pelimpah $=10 \mathrm{~m}$

Panjang sal. Transisi $=5 \mathrm{~m}$

Panjang sal. Peluncur lurus $=15 \mathrm{~m}$

Panjang saL.Peluncur terompet $=23 \mathrm{~m}$

Panjang kolan olak $=3,30 \mathrm{~m}$

Tipe kolam olak = USBR tipe 3 
Dimensi tubuh bendungan :

Lebar mercu $\quad=3,10 \mathrm{~m}$

Tinggi bendungan $\quad=11,5 \mathrm{~m}$

Elevasi mercu $=+106.50$

Kemiringan lereng hulu $=1: 2$

Kemiringan lereng hilir $=1: 2$

5. Dari perhitungan kestabilan tubuh bendungan metode Fellenius dan dengan Program DXSTABL didapat FS TERJADI < $\mathrm{FS}_{\text {IJIN }}$ (tidak memenuhi syarat). Maka untuk perkuatannya direncanakan menggunakan geotexile, jumlah geotextile yang dibutuhkan 11 lapis dipasang melintang pada timbunan bendungan dengan type geotextile yang dipilih adalah type Stabilenka 800/100. Sedangkan arah memanjang tubuh bendungan dipasang Geomembran HDPE tebal $2 \mathrm{~mm}$.

\section{DAFTAR PUSTAKA}

[1] Pekerjaan Umum, Dirjen. 1986. Kriteria Perencanaan 02 - Bangunan Utama. PU

[2] Angga Anugrah, PT. 2013. SID Embung Angsokah Sampang. Surabaya

[3] Cahyadi, A. D. Lasminto, U. dan Ansori, M. B. Redesain Bendungan Way Apu Kabupaten Buru Provinsi Maluku. Jurnal Hidroteknik, vol. 1, no. 2 (2015), pp 67-74.

[4] Endah, Noor. 2012. Modul Ajar Metode Perbaikan Tanah. Surabaya : Institut Teknologi Sepuluh Nopember

[5] Sosrodarsono, S., Takeda, K. 2006. Hidrologi untuk Pengairan. Jakarta: PT. Pradnya Paramita

[6] Sosrodarsono, S., Takeda, K. 2002. Bendungan Tipe Urugan. Jakarta: PT. Pradnya Paramita 